\title{
ゲルクロマトグラフィーによる直鎖アルキルベンゼン 中の傍生物質の定量
}

\author{
小西一生，井ノ上 裕夫*
}

$(1969$ 年 3 月 14 日受理)

\begin{abstract}
合成洗剤の原材料である直鎖アルキルベンゼンは傍生物質としてアルキルテトラリンやアルキルイン ダンを含えでいる，そこでこれらの傍生物質を定量するためセフォデックス LH-20を用いるゲルクロ マトグラフィーを検討した，ゲルクロマトグラフィーの条件として, 外径 $1.8 \mathrm{~cm}$, 長さ $260 \mathrm{~cm}$ のガ ラスカラムを使用し，展開溶媒としてイソプロパノール，試料添加量を $50 \mu l$ とした場合，フルキルベ ンゼンと傍生物質は分離することがわかった。市販の直鎖アルキルベンゼンについて分析した結果，ア ルキルベンゼンと傍生物質のピークは分離度 1 以上となり，その面積をプラニメーターで測定すること により定量することができた。
\end{abstract}

\section{1 緒言}

洗剂としてのすぐれた性能と廉価であるという理由 で，現在最も多量に使用され合成洗戍の大半を占めてい る直鎖アルキルベンゼンスルホン酸塩の原材料である直 鎖アルキルベンゼンは，そのフェニル基の結合位置に基 因する位置異性体分布やアルキル基分布122)のみならず, 傍生物質としてアルキルテトラリンやアルキルインダン を含えでいる2 2 5).これらの傍生物質は主成分のアルキ ルベンゼンといっしょにスルホン化されるが，そのスル ホン酸塩の洗浄剤としての性能はアルキルベンゼンスル ホン酸塩のそれと比較して劣ることが明らかにされてい る3).

これらの傍生物質はたとえばクロルアルカンとベンゼ ンから塩化アルミニウムを触媒としてアルキルベンゼン を製造する場合にはクロルアルカン中に含まれるジクロ ルアルカンによって生成するといわれている.<smiles>[R]C1CCC([R])c2ccccc21</smiles>

1,4-ジアルキルテトラリン

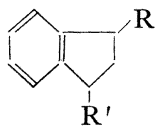

1,3-ジアルキルインダン
しかしながらこれら傍生物質は主成分であるアルキル ベンゼンと化学的性質が類似しているため信頼のおける

* 花王石䲓株式会社産業科学研究所 : 和歌山市湊薬種 畑
分析方法は確立されていなかった。

一方，ゲルクロマトグラフィーは近代生化学分野にお いてきわめて効果的に利用され，この分野の研究に画期 的な進展を促したが，新しい原理の導入のゆえに他の分 野においても今まで解決をみなかった多くの問題に新し い方法を提供したと考えられる。界面活性剤工業におけ るゲルクロマトグラフィーの分析化学的利用はきわめて そしいようであるが, 最近 Mair ら6) はセフォデックス LH-20 を用いるゲルクロマトグラフィーによってシク ロプロパンとパラフィン，およびアルキルインダンとア ルキルベンゼンの分離に成功している。しかしながら， この報交ではクロマトグラムが図示されておらず，また 分子量の小さいアルキルインダンとアルキルベンゼンの 1 組を扱っており，そこに示されているゲルクロマトグ ラフィーの条件を, 洗剤原料の直鎖アルキルベンゼン中 の傍生物質の分別定量に適用することはとうていできな い. そこで, 本報ではゲルクロマトグラフィーの条件と して, 展開溶媒の種類, カラムの大きさ, 試料添加量に ついて検討し，直鎖アルキルベンゼン中の傍生物質を定 量しうる条件を決定した結果について報告する。

\section{2 実験}

\section{1 装置および試薬}

溶出物質の検出とクロマトグラムの記録に自記記録式 差動屈折計 (Waters Associates Inc. R-4 Detector) 用いた. 外径 $1.5 \mathrm{~cm}, 1.8 \mathrm{~cm}$ および $2.3 \mathrm{~cm}$ ，長さ 260 $\mathrm{cm}$ の 3 種類のガラス製カラムを用い，溶出液はフラク 
ションコレクター（東洋科学産業， SF-160K 型）を用 いて捕集した。分別物の確認は質量分析計 (日立 RMU6D 型）を用いて行なった。展開溶媒の検討にはメタ, 一ル, エタノール, イソプロパノール, $n$-ブタノール, およびアセトンの特級試薬をそのまま使用した。カラム 内のゲル䊀子間げきの容積，すなわち void volume の 測定にはポリプロピレンオキサイド（平均分子量 5000) を使用し，ゲルクロマトグラフィーの最適条件の検索に は標準試料として，n-ブチルベンゼンとテトラリンの等 量混合物と $n$-ドデシルベンゼンとジブチルテトラリン の $5: 3$ 混合物を用いた。 また，分析試料として市販の 直鎖アルキルベンゼン 7 種を選び分析に供した。

\section{2 ゲルクロマトグラフィーの操作}

セフォデックス LH-20 をイソプロパノールに膨潤さ せたのち, 外径 $1.8 \mathrm{~cm}$ ，長さ $260 \mathrm{~cm}$ のガラス製カラ 厶に充てんし，1 昼夜展開溶媒を流してゲルを安定させ る。また展開溶媒のある一定の流速を得るために溶媒だ わを適当な高さに上げ，溶媒だめとカラム入口の間およ びカラム出口と差動屈折計の間は外径 $1.8 \mathrm{~mm}$ のポリ チレンチューブで連結する.

\section{3 分別物の定量方法}

傍生物質の定量はクロマトグラムの面積から行なっ た、すなわち，面積定プラニメーターで 3 回測定し，そ の平均值を求め，全面積に対寸る割合から算出した。分 離度 $R=1$ の場合においても分别侕のすをは重なってい

(a)

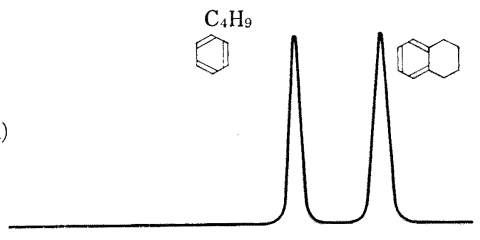

(b)

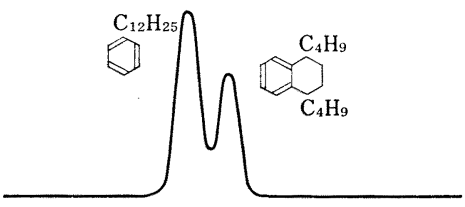

(c)

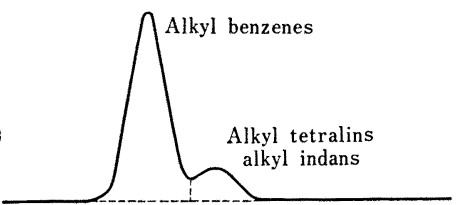

Fig. 1 Gel chromatogram

(a) Standard sample : Butylbenzene and tetralin; (b) Standard sample : $n$-Dodecylbenzene and, di-butyltetralin; (c) Commercial sample
るため Fig. 1-c のように二つの分別衙の重なりの中心 からベースラインに瑇線を㧍ろし，カーブと垂線とベー スラインに囲まれた二つの面積をプラニメーターで測定 した.

3 結 果

\section{1 展開溶媒の選定}

展開溶媒の種類によってゲルの膨潤度が異なり，これ が分離度を左右する重要な因子でもあるので，展開溶媒 の種類と分離度の関係を調べた。展開溶媒としてアセト ン，メタノール，エタノール，イソプロパノール，n-ブ タノールを用い, 外径 $1.8 \mathrm{~cm}$, 長さ $260 \mathrm{~cm}$ のカラム を使って，n-ドデシルベンゼンとジブチルテトラリンの 5 対 3 の混合物 $50 \mu l$ についてその分離度定調べた。 実験の結果得られた展開溶媒の種類と分離度の関係㳉 Table I に示した. Table I から実験の籁囲内でイソブ ロパノールが最も分離よく, そのた展開溶媒としてイ ソプロパノールを選定した。

Table I The relationship between developing solution and peak resolution

\begin{tabular}{lcc}
\hline $\begin{array}{c}\text { Developing } \\
\text { solution }\end{array}$ & $\begin{array}{c}\text { Peak resolution } \\
(R)\end{array}$ & $\begin{array}{c}\text { Number of theoretical } \\
\text { plate }(N) \dagger\end{array}$ \\
\hline Acetone & 0.77 & 2800 \\
Methanol & 0.54 & 1000 \\
Ethanol & 0.58 & 2200 \\
iso-Propanol & 0.87 & 4200 \\
$n$-Butanol & 0.47 & 2400 \\
\hline
\end{tabular}

G. P. C. condition-Standard sample : n-Dodecylbenzene and dibutyltetralin mixture (5:3); Sample size: $50 \mu l$; Column size : $1.8 \times 260 \mathrm{~cm}$; Flow rate: $17 \sim 20 \mathrm{ml} / \mathrm{hr}$; † The values were calculated for dodecyl benzene.

\section{2 カラムの大きさ}

展開溶媒としてイソプロパノールを用い，試料量 50 $\mu l$ とした場合に分離度が最も良好なカラムの大きさ索 決定するために，外径吢 $1.5 \mathrm{~cm} ， 1.8 \mathrm{~cm}$ ，および 2.3 $\mathrm{cm}$, 長さ $260 \mathrm{~cm}$ の 3 種類のカラムを用いて標準試料空 分析した。分析の結果得られたカラムの大きさと分離度 の関係法 Table II に示した. Table II からカラム注外 径 $1.8 \mathrm{~cm}$ ，長さ $260 \mathrm{~cm}$ のもの定使用することに決好 た。

\section{3 試料添加量}

展開溶媒としてイソプロパノール，カラム注外径 1.8 $\mathrm{cm}$, 長さ $260 \mathrm{~cm}$ のもの定使用した場合, 適当な分離度 が得られる試料添加量を決定すべく, 添加量を $10 ， 25$, $50,100 \mu l$ と变化させて分析を行なった．その結果得 
Table II The relationship between column size and peak resolution

\begin{tabular}{ccc}
\hline $\begin{array}{c}\text { Column size } \\
(\mathrm{cm})\end{array}$ & $\begin{array}{c}\text { Peak resolution } \\
(R)\end{array}$ & $\begin{array}{c}\text { Number of theoretical } \\
\text { plate }(N) \dagger\end{array}$ \\
\hline $1.5 \times 260$ & 0.33 & 2000 \\
$1.8 \times 260$ & 0.87 & 4200 \\
$2.3 \times 260$ & 0.85 & 3900 \\
\hline
\end{tabular}

G. P. C. condition-Standard sample : $n$-Dodecyl benzene and dibutyl tetralin mixture $(5: 3)$; Sample size : $50 \mu l$; Developing solution: iso-Propanol; Flow rate: $17 \sim 20 \mathrm{ml} / \mathrm{hr}$; $†$ The values were calculated for dodecyl benzene.

られた試料添加量と分離度の関係は Table III に示し た. Table III から試料添加量は $50 \mu l$ に決定した。

Table III The relationship between sample size and peak resolution

\begin{tabular}{ccc}
\hline $\begin{array}{c}\text { Sample size } \\
(\mu l)\end{array}$ & $\begin{array}{c}\text { Peak resolution } \\
(R)\end{array}$ & $\begin{array}{c}\text { Number of theoretical } \\
\text { plate }(N) \dagger\end{array}$ \\
\hline 100 & 0.78 & 3300 \\
50 & 0.87 & 4200 \\
25 & 0.78 & 3200 \\
10 & 0.78 & 3400 \\
\hline
\end{tabular}

G. P. C. condition-Standard sample : $n$-Dodecyl benzene ${ }^{\boldsymbol{\gamma}}$ and dibutyl tetralin mixture (5:3); Column size : $1.8 \times 260 \mathrm{~cm}$; Developing solution : iso-Propanol; Flow rate : $20 \mathrm{ml} / \mathrm{hr}$;

$\dagger$ The values were calculated for dodecyl benzene.

\section{4 ゲルクロマトグラムと 分別成分の 質量分析の結} 果

上述のような実験から定めた条件で，市販の直鎖アル キルベンゼンと標準試料について行なったゲルクロマト グラフィーの結果を Fig. 1 に示した。 n-ドデシルベン ゼンとジブチルテトラリンを混合した標準試料のゲルク ロマトグラムから，市販の直鎖アルキルベンゼンのゲル クロマトグラムの前のピークはアルキルベンゼン，あと のピークは傍生物質のアルキルテトラリン類と推定され る.

この点をさらに確認するために溶離液の 各フラクシ シンについて質量分析を行なった結果，前のピークは $\mathrm{C}_{n} \mathrm{H}_{2 n-6}$ の成分，すなわちアルキルベンゼンで，あと のピークは $\mathrm{C}_{n} \mathrm{H}_{2 n-8}$ の成分, すなわらアルキルテトラ リンとアルキルインダンであることを確かめた. マスス ペクトルの結果を Fig. 2 に示した. Fig. 2 中の解析例 は，分析試料中のおもな成分について示したものであ る.

\section{5 既知混合物の分析結果}

$n$-ドデシルベンゼンとジブチルテトラリンを一定割合
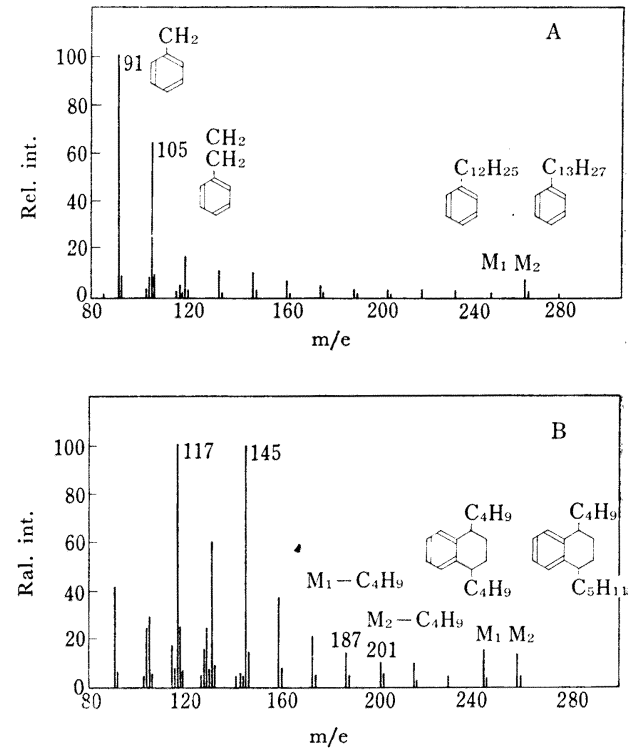

Fig. 2 Mass spectra

A : Head peak; B : Tail peak

で混合して調製した既知混合物について，上述の方法で 分析した結果を Table IV に示した. Table IV から分 析值と計算值の一致注良好である.

Table IV Results of known mixture determination

\begin{tabular}{ccccc}
\hline & Sample (No.) & Taken (\%) & Found (\%) \\
\hline \multirow{2}{*}{1} & \multirow{2}{*}{2} & $\left\{\begin{array}{l}n \text {-Dodecyl benzene } \\
\text { Dibutyl tetralin }\end{array}\right.$ & 62.5 & 62.6 \\
& $\left\{\begin{array}{l}n \text {-Dodecyl benzene } \\
\text { Dibutyl tetralin }\end{array}\right.$ & 73.6 & 37.4 \\
& & & 26.4 & 72.8 \\
\end{tabular}

G.P. C. condition-Sample size : $50 \mu l$; Column size : $1.8 \times$ $260 \mathrm{~cm}$; Solvent : iso-Propanol; Flow rate: $20 \mathrm{ml} / \mathrm{hr}$

\section{6 市販製品の分析結果}

7 種類の市販の直鎖アルキルベンゼンについて分析を 行ない，その傍生物質を定量し，その結果を Table V に示した. Table V から市販の直鎖アルキルベンゼン に勏生物質としてアルキルテトラリンとアルキルイン ダンが約 2〜10\% 含まれていることがわかった。

\section{7 カラムの特性と溶質の分配係数}

使用したカラム特性を明らかにするとともに，溶質の 分配係数 $K d$ を算出するため, 市販の直鎖アルキルベン ゼンを分析する際のカラムの全容積 $V_{\mathrm{t}}$, void volume $V_{\mathrm{o}}$, 溶質の保持容量 $V_{\mathrm{e}}$ を測定した. 用いた乾燥ゲルの 量a汢 $130 \mathrm{~g}$ である・結果をまとめると 
Table V Results of commercial sample determination

\begin{tabular}{ccc}
\hline $\begin{array}{c}\text { Commercial } \\
\text { sample }\end{array}$ & $\begin{array}{c}\text { Alkyl benzenes } \\
(\%)\end{array}$ & $\begin{array}{c}\text { Alkyl tetralins } \\
\text { Alkyl indans } \\
(\%)\end{array}$ \\
\hline A & 90.6 & 9.4 \\
B & 94.3 & 5.7 \\
C & 91.0 & 9.0 \\
D & 95.5 & 4.5 \\
E & 97.5 & 2.5 \\
F & 93.7 & 6.3 \\
G & 96.5 & 3.5 \\
\hline
\end{tabular}

G. P. C. condition-Sample size : $50 \mu l$; Column size : $1.8 \times$ $260 \mathrm{~cm}$; Solvent : iso-Propanol ; Flow rate: $20 \mathrm{ml} / \mathrm{hr}$

$\begin{array}{lr}V_{\mathrm{t}} & 420 \mathrm{~m} l \\ V_{\mathrm{o}} & 125 \mathrm{~m} l \\ V_{\mathrm{e} 1} & 268 \mathrm{~m} l \\ V_{\mathrm{e} 2} & 291 \mathrm{~m} l \\ V_{\mathrm{g}} & 78 \mathrm{~m} l\end{array}$

ただし $V_{\mathrm{e} 1}$ はアルキルベンゼンの， $V_{\mathrm{e} 2}$ はアルキルテ トラリン類の保持容量, $V_{\mathrm{g}}$ はゲル自体の容積である. これらの值を次の関係式に代入して, inner solvent の 容積 $V_{\mathrm{l}}$, solvent regain, $S_{\mathrm{r}}$ および分配係数を算出し た。

$$
\begin{aligned}
& V_{\mathrm{t}}=V_{\mathrm{o}}+V_{\mathrm{i}}+V_{\mathrm{g}} \\
& V_{\mathrm{i}}=S_{\mathrm{r}} \cdot \mathrm{a} \\
& K d=\frac{V_{\mathrm{e}}-V_{\mathrm{o}}}{V_{\mathrm{i}}}
\end{aligned}
$$

以上より

$\begin{array}{lr}V_{\mathrm{i}} & 217 \mathrm{ml} \\ S_{\mathrm{r}} & 1.67 \\ K d_{1} & 0.67 \\ K d_{2} & 0.77\end{array}$

ただし $K d_{1}$ はアルキルベンゼンの， $K d_{2}$ はアルキル テトラリン類の分配係数である.

\section{4 考察}

セフォデックス LH-20 が芳香核を有する化合物に対 乙て親和力を持ち, それが特にアルコール類を展開溶媒 に用いた場合に著しいことが指摘》されているので，展 開溶媒の選定にはアルコール類を検討した．この結果イ ソプロパノールを展開溶媒に選えだが，この展開溶媒を 用いた場合，アルキルベンゼンとアルキルテトラリン類 の分配係数がともに 1 以下であることはその分離の機構 が主として分子ふるい効果によることを示しているもの
と考える・

Fig. 1 において $n$-ブチルベンゼンとテトラリンは完 全に分離するのに対し， $n$-ドデシルベンゼンとジブチル テトラリンの分離はこれに比べるとわるくなっている. $n$-ドデシルベンゼンの保持容量は $n$-ブチルベンゼンの それより少ないが，その減少の程度はテトラリンに対す るジブチルテトラリンの保持容量の減少の程度より少な い. このことは $n$-ドデシルベンゼンとジブチルテトラ リンの分離をわるくする要素の一つと考えられる。すな わち分離に及ぼすアルキル基の効果は大きく, アルキル 基の置換あるいはアルキル基の増大はアルキルベンゼン とアルキルテトラリン類の分離を悪化させる方向にある と考えられる。

直鎖アルキルベンゼンはアルキル基分布とフェニル基 の位置異性体分布があり， $n$-ドデシルベンゼンとは若干 その保持容量が異なるようである. すなわち $n$-ドデシ ルベンゼンの保持容量が $275 \mathrm{ml}$ であるのに対し, 直鎖 アルキルベンゼンの保持容量は $268 \mathrm{ml}$ でその差は $7 \mathrm{ml}$ である.一方， ジブチルテトラリンとアルキルテトラリ ン類の保持容量はともに $291 \mathrm{ml}$ と等しいので, 直鎖ア ルキルベンゼンの分析では分離度が 1 以上とよくなる.

分離度 $R$ は二つのピークの保持容量の差を二つのピー クの幅の平均值で除したものをいうが，Fig. 3 から明ら かなように $R=1$ のとき二つのピークはほぼ分離する。 $R=1$ という限界の分離を達成するに必要な理論段数 $N$ は，分離係数を $S_{\mathrm{F}}$ とすると次の関係式がなりたつ.

$$
\begin{gathered}
N=4\left(\frac{S_{\mathrm{F}}+1}{S_{\mathrm{F}}-1}\right)^{2} \fallingdotseq \frac{16}{\left(S_{\mathrm{F}}-2\right)^{2}} \\
\text { したがって } S_{\mathrm{F}}=1.09 \text { では } N \fallingdotseq 2000 \text { となり, 本研究 }
\end{gathered}
$$
に用いたカラムの理論段数は 4200 であるから，直鎖ア

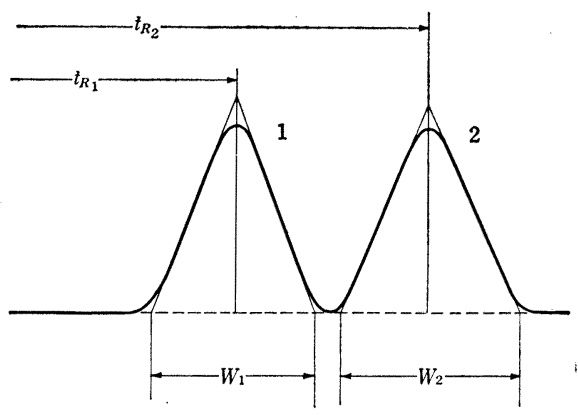

Fig. 3 Peak resolution $(R)$ and resolution factor $\left(S_{\mathrm{F}}\right)$

$$
R=\frac{2\left(t_{R_{2}}-t_{R_{1}}\right)}{W_{1}+W_{2}} \quad S_{\mathrm{F}}=\frac{t_{R_{2}}}{t_{R_{1}}}
$$


ルキルベンゼンとアルキルテトラリン類の分離に必要な カラム条件を満たしていると考える.

分離度そのものはカラムの長さを長くすることにより 大きくすることも可能であるが，本研究で使用した 260 $\mathrm{cm}$ 以上のカラムは操作が不便となり, 室内で取り扱う のが困難である・また一定の長さのカラムを接続する方 法は, 特殊な接続器具を使用する場合を除いて接続部分 で溶質の拡散が起こり，分離度の向上は期待できない.

市販のアルキルベンゼンのなかには通常のものと比較 してアルキル分布がかなり広い製品も存在するが，この 種のものに法本法は適用できない.

\section{交献}

1) W. J. Carnes: Anal. Chem., 36, 1197 (1964).

2) R. S. Bloch : Oil Gas J., 1967, No. 1,79.

3) R. C. Taylor, B. J. Meehan, W. J. Dewitt, J. C. Reid : Paper 45, presented at the A. O. C. S., Meeting in Los Angeles, April (1966).

4) P. W. Flanagan, M. C. Hamming, F. M. Evens : J. Am. Oil Chemists' Soc., 44, 30(1967).

5) 木村 鎮, 永山升三, 川名輝之助：表面，6,767
(1968)

6) B. J. Mair, P. T. R. Hwang, R. G. Ruberto : Anal. Chem., 39, 838 (1967).

7) S. Milk, J. Rochlitz, H. Bende : J. Chromatog., 24, 414 (1966).

$$
\text { is }
$$

Determination of by-products in linear alkyl benzene by gel-chromatography. Kazuo KoNisH and Hiroh Inoue (Industrial Research Laboratories, Kao Soap Co., Ltd., Minatoyakushubata, Wakayamashi)

Linear alkyl benzene used extensively in the detergent industry contains usually small amounts of alkyl tetralins and alkyl indans as by-products. Determination of these by gel chromatography on Sephadex LH-20 was investigated. The optimum analytical conditions were : developing solution isopropanol, glass column $1.8 \mathrm{~cm}$ in diameter and $260 \mathrm{~cm}$ in length and sample size $50 \mu l$. Peak resolution between linear alkyl benzene and impurities in commercial products was more than unity. The contents of by-products were determined by comparison of chromatographic peak areas measured by a planimeter.

(Received Mar. 14, 1969)

\title{
$\mathbf{X}$ 線カントメーターによる重油中イオウのけい光 $\mathbf{X}$ 線分析
}

\author{
柳ケ瀬健次郎*
}

(1969 年 3 月 31 日受理)

\begin{abstract}
液体試料容器に入れた重油中の残留気ほうが真空下で膨張し，マイラー面を隆起させることが分析精 度低下の主因をなすのでこの対策について検討した。 まず計測器を試作し，ガラス製真空容器内におけ るマイラ一面の隆起の高さを実測し，これと試料温度残留気量の大小およびマイラーはくの厚みとの関 係を調べた。次に $\mathrm{Rh}$ 対陰極 $\mathrm{X}$ 線管球を用いた散乱 $\mathrm{RhL}_{\boldsymbol{\alpha}} \mathrm{X}$ 線内標準のほうが， $\mathrm{Cr} \mathrm{X}$ 線管球による $\mathrm{CrK}_{\alpha}$ 内標準法よりも残留気ほうの大小によるX線強度の变動を補正する効果があることを示した。次 に重油を多数の液体試料容器に入れたとき， $9 \mu$ 厚のマイラーはくを使用するほうが 4 または $6 \mu$ のも のよりも残留気ほうが少なかった。またアスファルト（イオウ: $5.20 \%$ ）と固型パラフィンを適当な割 合で溶解固化させたものは，重油標準試料を入れた液体容器のように測定のたびごとに，新たに重油を 入れてマイラーはくを取り替える必要がなく, 120 回の分析後も安定したX線強度を示した.
\end{abstract}

\section{1 緒 $\overline{\overline{\bar{a}}}$}

散乱X線内標準による重油中のイオウのけい光X線分 析法について，既報》に引き続き実用性に富む手段追求 のため下記の諸項目について若干の検討を行ない結果を

* 九州電力株式会社総合研究所 : 福岡市塩原アイゾ
報告する．
（a）マイラー膜表面隆起に基因する誤差に対し，そ の隆起の高さを測定した。
（b）分析試料の冷却温度を $-5^{\circ} \mathrm{C}$ とした場合につ いて検討した.
（c） マイラー膜の厚さによる残留気ほう量の変化を 